\title{
UPAYA PENINGKATAN PEMAHAMAN NORMA HUKUM DAN KEDISIPLINAN DENGAN PERBANDINGAN MODEL PROJECT CITIZEN DAN COOPERATIVE SCRIPT
}

\author{
Nurul Wahyi Fithry \\ Universitas Negeri Padang, Padang \\ nurulwahyi121@gmail.com
}

\begin{abstract}
Abstrak
Penelitian ini dilatar belakangi oleh rendahnya pemahaman konsep dan kedisiplinan peserta didik dalam pembelajaran PPKn. Hal ini disebabkan oleh kecenderungan guru dalam menggunakan model konvensional sehingga belum bisa mengembangkan pemahaman konsep dan juga kurangnya kedisiplinan peserta didik dalam melakukan aktivitas di kelas ketika pembelajaran. Model adaptif, yang mendorong peserta didik dan guru melakukan pembelajaran yang efektif yaitu pertama pembelajaran Project Citizen dan kedua pembelajaran Cooperative Script. Penelitian ini bertujuan untuk melihat perbandingan kedua model tersebut, manakah yang lebih meningkatkan pemahaman konsep dan kedisiplinan peserta didik di kelas VII 8 dan VII 9 dalam pembelajaran PPKn di MTsN 1 Pasaman. Penelitian ini menggunakan pendekatan kuantitatif dengan metode penelitian eksperimen kuasi dengan Pre test-post test control group design. Hasil penelitian menunjukkan bahwa (1) Nilai rata-rata siswa dengan model pembelajaran Project Citizen (80.26) lebih tinggi dibanding dengan model pembelajaran Cooperative Script (75.13) (2) 9 siswa (23.07\%) memiliki tingkat kedisiplinan cukup pada model Project Citizen dan 12 siswa (30.76\%) pada model Cooperative Script. (3) Terdapat perbedaan yang signifikan pemahaman konsep siswa dengan model pembelajaran Project Citizen dan model pembelajaran Cooperative Script $(\square=0.000)$ (4) Tidak terdapat perbedaan yang signifikan kedisiplinan siswa dengan model pembelajaran Project Citizen dan model pembelajaran Cooperative Script $(\square=0.589)$. Dapat disimpulkan bahwa model pembelajaran Project Citizen lebih baik dalam meningkatkan pemahaman siswa dibanding dengan model pembelajaran Cooperative Script, namun dalam meningkatkan kedisiplinan siswa tidak terdapat perbedaan antara kedua model pembelajaran.
\end{abstract}

Kata kunci: Project Citizen; Cooperative Script; Norma Hukum; Disiplin. 
e-ISSN : 2621-4105

\title{
EFFORTS TO IMPROVE THE UNDERSTANDING OF LEGAL NORMS AND DISCIPLINE BY COMPARING THE CITIZEN PROJECT MODEL AND COOPERATIVE SCRIPT
}

\begin{abstract}
This research was motivated by the low understanding of the concept and discipline of students in learning PPKn. This is due to the tendency of teachers to use conventional models so that they have not understanding of students' concepts, and also the lack of discipline of students in carrying activities in class when learning. Adaptive model that encourages students and teachers to do effective, namely first Project Citizen learning and secondly Cooperative Script learning. This study aims to see the comparison of the two models, which one further improves 'understanding of concepts and students' discipline material in grades VII 8 and VII 9 at MTsN 1 Pasaman. This study uses a quantitative approach with a quasi-experimental research method with a Pre test-post test control group design. Data collection techniques are tests, questionnaires and observations. The sampling technique was simple random sampling. Data analysis using SPSS, with t-test analysis. The results showed that (1) the average score of students with the Project Citizen learning model (80.26) was higher than the Cooperative Script learning model (75.13) (2) 9 students (23.07\%) had sufficient discipline level in the Project Citizen model and 12 students (30.76\%) on the Cooperative Script model. (3) There is a significant difference in students' conceptual understanding with the Project Citizen learning model and the Cooperative Script learning model $(=0.000)(4)$ There is no significant difference in student discipline with the Project Citizen learning model and the Cooperative Script learning model (= 0.589). It can be concluded that the Project Citizen learning model is better at increasing student understanding than the Cooperative Script learning model, but in improving student discipline there is no difference between the two learning models.
\end{abstract}

Keywords: Project Citizen; Cooperative Script; Legal Norms, Discipline. 
e-ISSN : 2621-4105

\section{A. PENDAHULUAN}

Pendidikan pada dasarnya adalah usaha sadar untuk menumbuh kembangkan potensi sumber daya manusia peserta didik dengan cara mendorong dan memfasilitasi kegiatan belajar mereka. Pendidikan merupakan salah satu pilar utama dalam menentukan perubahan sosial. Perubahan ke arah kemajuan dan kesejahteraan hidup yang berkualitas. Pendidikan bertanggungjawab atas terciptanya generasi bangsa yang paripurna, sebagaimana tercantum dalam garis-garis besar haluan negarayaitu terwujudnya masyarakat Indonesia yang damai, demokratis,berkeadilan, berdaya saing, maju dan sejahtera, dalam wadah Negara Kesatuan Republik Indonesia yang didukungoleh manusia sehat, mandiri,beriman, bertakwa, berakhlak mulia, cinta tanah air, berkesadaran hukum dan lingkungan, menguasai ilmu pengetahuan dan teknologi, memiliki etos kerjayang tinggi serta berdisiplin. ${ }^{1}$

Pembelajaran merupakan suatu proses penyaluran informasi atau pesan dari pendidik ke peserta didik yang direncanakan, didesain, dilaksanakan, dan dievaluasi secara sistematis yang dilakukan di sekolah maupun di luar sekolah dimana akan terjadi interaksi antara keduanya. Pembelajaran dapat dipandang dari dua sudut,pertama,pembelajaran dipandang sebagai suatu sistem, pembelajaran terdiri dari sejumlah komponen yang terorganisasi antara lain tujuan pembelajaran, materi pembelajaran, strategi dan metode pembelajaran, media pembelajaran, dan tindak lanjut pembelajaran (remedial dan pengayaan). Kedua,pembelajaran dipandang sebagai suatu proses, maka pembelajaran merupakan rangkaian upaya atau kegiatan pendidik dalam rangka membuat peserta didik belajar. ${ }^{2}$

Guru merupakan salah satu faktor yang dapat mempengaruhi kualitas pendidikan. Sebab guru merupakan pengatur sekaligus pelaksana dalam proses pembelajaran yang berlangsung. Oleh sebab itu, guru harus memikirkan dan membuat perencanaan secara seksama dalam meningkatkan kesempatan belajar bagi siswanya dan memperbaiki kualitas mengajarnya. ${ }^{3}$ Kualitas belajar ini diperlukan oleh semua mata pelajaran terutama PPKn. Sapriya berpendapat bahwa pembelajaran Pendidikan Kewarganegaraan selayaknya dapat membekali siswa dengan pengetahuan dan keterampilan intelektual

\footnotetext{
${ }^{1}$ Achmad Patoni. 2004, “Dinamika Pendidikan Anak”. Jakarta: PT. Bina Ilmu.

${ }^{2}$ Kokom Komalasari, 2011, "Pembelajaran Kontekstual Konsep dan Aplikasi”, Bandung : Refika Aditama.

${ }^{3}$ Moch. User Usman, 2011, "Menjadi Guru Profesional”, Bandung : Remaja Rosdakarya.
} 
e-ISSN : 2621-4105

yang memadai serta pengalaman praktis yang harus dimiliki siswa agar kompetensi siswa dapat diterapkan dalambenyuk parttisipasi. ${ }^{4}$

Norma hukum adalah "peraturan hidup yang menentukan bagaimana manusia itu seyogyanya berperilaku, bersikap di dalam masyarakat agar kepentingannya dan kepentingan orang lain terlindungi”. Atau dalam arti sempit kaidah hukum adalah nilai yang terdapat dalam peraturan konkret

Madrasah Tsanawiyah (MTs) sebagai SLTP/SMP yang berada dalam lingkup Kementerian Agama, telah memiliki kesamaan struktur maupun fungsi kelembagaannya dengan SLTP/SMP yang berada dalam pembinaan Kemendikbud. Telah ditegaskan bahwa dalam Undang-undang No.20 Tahun 2003 tentang Sistem Pendidikan Nasional, bahwa secara yuridis formal satuan pendidikan madrasah (kementerian Agama RI) dan sekolah (Kementerian Pendidikan Nasional RI) memiliki kesamaan derajat di mata hukum. Dengan menempatkan posisi MTs ke dalam jalur utama pendidikan sekolah seperti yang digariskan dalam Undang-Undang mengenai Sistem Pendidikan Nasional, maka dengan sendirinya Madrasah Tsanawiyah dapat menunaikan peran pentingnya dalam peningkatan mutu pendidikan tingkat menengah pertama. MTs sebagai salah satu lembaga penyelenggara pendidikan formal terus berupaya untuk meningkatkan mutu pendidikan di Kabupaten Pasaman guna mencapai tujuan pendidikan nasional dengan tantangan era globalisasi. Masalah yang dihadapi dunia pendidikan adalah masalah lemahnya proses pembelajaran, begitu pula yang terjadi di sebagian besar MTs yang ada di Kabupaten Pasaman.

Penelitian tentang pembelajaran Kewarganegaraan pernah dikaji oleh Norlaili Hidayati dengan judul "Meningkatkan Kecakapan Kewarganegaraan (Civic Skill) Melalui Pembelajaran Pkn Berbasis Project Citizen (Studi Kuasi Eksperimen Di SMK YPT Banjarmasin)", dalam penelitiannya tersebut dijelaskan bahwa Project Citizen merupakan model pembelajaran yang dapat mengembangakan kompetensi siswa khususnya berkenaan dengan kecakapan siswa, yaitu sebuah model pembelajaran berbasis portofolio. Dengan menggunakan model ini para siswa bukan hanya diajak untuk memahami konsep dan keilmuan, tetapi juga mengembangkan kemampuannya untuk bekerja secara kooperatif melalui kegiatan belajar praktik empirik. Tentunya

${ }^{4}$ Sapriya, dan US Winataputra, 2004, "Pendidikan Kewarganegaraan:Model Pengembangan Materi Dan Pembelajaran”, Bandung : Lab. PKn UPI Bandung. 
e-ISSN : 2621-4105

akan menghasilkan pembelajaran yang semakin menantang, mengaktifkan dan lebih bermakna. Model ini mengajak siswa untuk memecahkan masalah riil dalam kehidupanbermasyarakat, berbangsa dan bernegara. $\mathrm{Di}$ sini siswa belajar menemukan alternatif pemecahan masalah. Di samping itu, siswa juga mengembangkan proses penalaran dan klarifikasi nilai. Kemudian siswa mengembangkan usul kebijakan publik dan mengusulkan rencana tindakan. Dengan demikian diharapkan mampu meningkatan kualitas pembelajaran Pendidikan Kewarganegaraan agar menjadi "subjek pembelajaran yang kuat"(powerful learning area). ${ }^{5}$

Sedangkan pnelitian Ni Pt. Dyan Febriyanti1, I Nym. Laba Jayanta (2018) dengan judul "Pengaruh Model Pembelajaran Cooperative Script Berbantuan Penilaian Portofolio terhadap Hasil Belajar PKn".Penelitian ini menganalisis perbedaan yang signifikan model pembelajaran Cooperative Script berbantuan penilaian portofolio terhadap hasil belajar PKn siswa kelas III di SD Gugus XIV Kecamatan Buleleng Kabupaten Buleleng Tahun Pelajaran 2017/2018. Jenis penelitian ini adalah penelitian eksperimen semu dengan rancangan non equivalent post-test only control group desain. Data hasil belajar dikumpulkan dengan menggunakan metode tes pilihan ganda/obyektif. Data yang diperoleh dianalisis dengan menggunakan teknik analisis statistik deskriptif dan statistik inferensial yaitu uji-t. Hasil penelitian menunjukkan terdapat perbedaan yang signifikan antara siswa kelas III yang mendapat perlakuan model pembelajaran Cooperative Script berbantuan penilaian portofolio dengan siswa yang tidak dibelajarkan menggunakan model pembelajaran. ${ }^{6}$

Selanjutnya penelitian oleh Nika Fetria Trisnawati dkk (2019) yang berjudul "Pengaruh Model Cooperative Script Terhadap Hasil Belajar Siswa Kelas IX SMP Negeri 1 Kota Sorong". Penelitian tersebut menganalisis bagaimana pengaruh dari penerapan model Cooperative Script terhadap hasil belajar. Penelitian ini merupakan penelitian Quasi Experimental Design dengan desain eksperimen Non-Equivalent Pre test-Post test Design. Populasi penelitian mencakup seluruh siswa kelas IX SMP Negeri

${ }^{5}$ Norlaili Hidayati, “Meningkatkan Kecakapan Kewarganegaraan (Civic Skill) Melalui Pembelajaran Pkn Berbasis Project Citizen (Studi Kuasi Eksperimen Di SMK YPT Banjarmasin)”, Jurnal Socius 2 (2), 2013.

DOI: $10.20527 /$ jurnalsocius.v2i2.2205

6 Ni Pt. Dyan Febriyanti1, I Nym. Laba Jayanta, "Pengaruh Model Pembelajaran Cooperative Script Berbantuan Penilaian Portofolio terhadap Hasil Belajar PKn”, Jurnal Mimbar PGSD UNDHIKSA 6 (2) 2, 2018. DOI: http://dx.doi.org/10.23887/jipgsd.v6i2.19468 
e-ISSN : 2621-4105

1 Kota Sorong dengan dua kelas sebagai sampel acak, kelas IX A sebagai kelas eksperimen dengan memberikan perlakuan berupa penerapan model Cooperative Script pada pembelajaran dikelas dan kelas IX B sebagai kelas kontrol dengan tidak memberikan perlakuan khusus. Perangkat yang digunakan untuk pengumpulan data adalah lembar observasi dan soal Pre test-post test. Hasil penelitian menunjukkan adanya pengaruh positif yang signifikan dari penerapan model Cooperative Script terhadap hasil belajar kelas IX A SMP Negeri 1 Kota Sorong. ${ }^{7}$

Yang membedakan penelitian ini dengan penelitian-penelitian lainnya adalah pertama, penelitian ini melihat bagaimana cara meningkatkan pemahaman konsep dan kedisiplinan siswa dalam materi norma hukum di MTsN 1 Pasaman. Kedua penelitian ini membandingkan dua model pembelajaran yaitu Project Citizen dan Cooperative Script manakah yang lebih efektif. Penelitian ini dilatar belakangi oleh rendahnya pemahaman konsep dan kedisiplinan peserta didik dalam pembelajaran PPKn. Hal ini disebabkan oleh kecenderungan guru dalam menggunakan model konvensional sehingga belum bisa mengembangkan pemahaman konsep dan juga kurangnya kedisiplinan peserta didik dalam melakukan aktivitas di kelas ketika pembelajaran. Model adaptif, yang mendorong peserta didik dan guru melakukan pembelajaran yang efektif yaitu pertama pembelajaran Project Citizen dan kedua pembelajaran Cooperative Script. Penelitian ini bertujuan untuk melihat perbandingan kedua model tersebut, manakah yang lebih meningkatkan pemahaman konsep dan kedisiplinan peserta didik di kelas VII 8 dan VII 9 dalam pembelajaran PPKn di MTsN 1 Pasaman.

\section{B. PERMASALAHAN}

Berdasarkan hasil uraian di lalar belakang penelitian dapat disimpulkan bahwa permasalahan yang diangkat di penelitian ini bagaimana tingkat pemahaman dan kedisiplinan pelajar menengah tentang norma hukum?

\section{METODE PENELITIAN}

Penelitian ini menggunakan pendekatan Bentuk quasi eksperimen design (eksperimen semu) yang digunakan dalam penelitian ini adalah Counterbalanced Design. Penelitian ini dilaksanakan di MTsN 1 Pasaman. Teknik Pengembilan sampel adalah

${ }^{7}$ Nika Fetria Trisnawati dkk, "Pengaruh Model Cooperative Script Terhadap Hasil Belajar Siswa Kelas IX SMP Negeri 1 Kota Sorong”, Jurnal ADMATHEDU 9 (2), 2019, hal 123-134.

DOI: http://dx.doi.org/10.12928/admathedu.v9i2.14858 
e-ISSN : 2621-4105

simple purposive sampling yaitu menentukan pengambilan sampel dengan cara menetapkan ciri-ciri khusus yang sesuai dengan tujuan penelitian sehingga diharapkan dapat menjawab permasalahan penelitian. Penelitian ini memilih kelas VII.8 dan kelas VII.9. Sampel dalam penelitian ini adalah siswa kelas VII. 8 dan VII. 9 di MTsN 1 Pasaman yang berjumlah 384 siswa sampel nya berjumlah 78 siswa.

Penelitian ini memilih kelas VII.8 sebagai kelas eksperimen 1 dengan mengunakan model pembelajaran Project Citizen dan kelas VII.9 sebagai kelas eksperimen 2 dengan mengunakan model pembelajaran cooperative script. Kedua kelas mendapatkan materi pembelajaran yang sama yaitu materi norma hukum dalam mata pelajaran PPKn.

Penelitian ini mengunakan desain penelitian pre test-post test control group design untuk melihat peningkatan pemahaman konsep peserta didik pada kedua model pembelajaran seperti ditunjukkan tabel 3. Sedangkan utuk melihat peningkatan kedisiplinan peserta didik peneliti mengunakan metode angket sebagaimana terlihat pada tabel 4.

Tabel 1. Desain Penelitian Pre Test-Post Test Control Group Design.

\begin{tabular}{llll}
\hline Kelas & Pre test & Perlakuan & Post test \\
\hline Eksperimen 1 & $\mathrm{O} 1$ & $\mathrm{X} 1$ & $\mathrm{O} 2$ \\
Ekesperimen 2 & $\mathrm{O} 3$ & $\mathrm{X} 2$ & $\mathrm{O} 4$ \\
\hline
\end{tabular}

Dimana O1,O2,O3 dn O4 merupakan hasil pre test dan post tes kelas experiment 1 dan kels eksperimen 2. Sedangkan X1 dan X2 adalah perlakuan pada kelas ekseprimen 1 dan kelas eksperimen 2. Hasil pre test dan post test kedua kelas dengan berbeda perlakuan tersebut dianalisa dan dibandingkan sehingga dapat ditarik kesimpulan bagaimana peningkatan pemahaman konsep peserta didik pada kedua kelas eksperimen.

\section{Tabel 2. Angket Penelitian}

\begin{tabular}{lll}
\hline Kelas & Perlakuan & Angket Akhir \\
\hline Ekperimen 1 & $\mathrm{X} 1$ & $\mathrm{~T}$ \\
Eksperimen 2 & $\mathrm{X} 2$ & $\mathrm{~T}$ \\
\hline
\end{tabular}


e-ISSN : 2621-4105

Dimana $\mathrm{T}$ merupakan hasil angket pada kelas eksperimen 1 dan eksperimen 2 dengan berbeda perlakuan. Dalam penelitian ini angket atau kuesioner diberikan kepada siswa yang dikelas eksperimen 1 dan kelas eksperimen 2 untuk mengetahui tingkat kedisiplinan siswa melalui pengajaran pendidikan pancasila dan kewarganegaraan dengan materi norma hukum.

Tujuan dari penelitian eksperimen ini adalah untuk mengetahui dan menyelidiki ada tidaknya pengaruh dan hubungan sebab akibat suatu model yang dilakukan atau yang diujikan oleh peneliti dengan cara memberikan perlakuan-perlakuan tertentu pada beberapa kelompok yang diujikan, yaitu pada kelompok eksperimen 1 dan kelompok eksperimen 2 yang telah ditentukan.

Data yang dikumpulkan berasal dari instrument yang disebarkan peneliti. Instrumen yang digunakan berupa lembar pertanyaan Pre test dan post test berupa soal tentang norma hukum dengan jenis pertanyaan pilihan ganda, sedangkan angket kedisiplinan siswa menggunakan instrument dengan 4 poin sesuai dengan metode likert. Teknik analisis data mengunakan data kuantitatif. Data dianalisis terlebih dahulu menggunakan uji prasyarat berupa uji normalitas, uji homogenitas, uji paired-samples $\mathrm{T}$ Test, dan uji independent-samples $\mathrm{T}$ Test.

\section{HASIL DAN PEMBAHASAN}

\section{Hasil Pemahaman Konsep Siswa Melalui Konsep Norma Hukum}

Dalam penelitian ini menganalisis pemahaman konsep siswa, pemahaman konsep lebih tinggi tingkatannya dari pada menghafal, pemahaman konsep menyusun dan menyimpulkan dengan kalimat sendiri, konsep-konsep yang telah di ajarkan oleh guru maupun yang di dapat dari sumber lain. Dari pengertian ini dirasakan sangat cocok sekali dengan menerapkan Project Citizen dan Cooperative Script karena, dalam proses pembelajaran ini memang di tuntut siswa untuk mampu mengemukakan pendapatnya meskipun tidak saja tatap muka namun bisa juga melalui online, karena mengingat keadaan saat sekarang ini. Yang kedua adalah kedisiplinan, kedisiplinan di madrasah adalah melihat perilaku peserta didik tidak saja di madrasah namun juga di rumah, tata tertib yang ada, aturan yang telah disepakati dan telah dibuat.

Dari pengamatan yang dilihat langsung terdapat beberapa masalah yang pertama dalam proses pembelajaran siswa kurang didorong untuk mengembangkan kemampuan 
e-ISSN : 2621-4105

berpikir kritis, siswa lebih cenderung diarahkan untuk menghafal, menimbun informasi sehingga siswa cenderung pasif dalam belajar, yang kedua siswa lebih cenderung suka mendengar, menulis atau mencatat materi yang diajarkan. Belum adanya timbal balik yang dilakukan dalam berinteraksi guru dengan siswa yang bertanya dan menjawab cenderung siswa itu-itu saja. ketiga yang terjadi adalah siswa dalam memberikan contohcontoh real atau nyata di kehidupan sehari-hari sesuai dengan materi pelajaran belum bisa memberikan pendapatnya, belum bisa berpikir luas, siswa cenderung memberikan contoh-contoh yang telah disampaikan oleh guru maupun yang ada di dalam buku. Dengan melakukan pengamatan dengan tanya jawab dengan siswa bisa dikatakan mereka belum menyisihkan waktu untuk menggali informasi dari berbagai media. Selanjutnya, yang keempat guru cenderung memberikan model atau metode pembelajaran yang monoton masih kurang kreatif seperti ceramah, sesekali dengan diskusi. Kurang adanya variasi yang membuat siswa bosan, monoton ditambah lagi dengan pembelajaran di madrasah itu dua kali lipat dibandingkan dengan SMP. Yang kelima bahan ajar siswa masih sangat minim seperti LKS dan Buku Cetak yang tersedia di perpustakaan. Siswa mengumpulkan informasi dari sumber itu saja.

Tingkat kognitif siswa yang rendah akan semakin dirasakan guru bidang studi pada saat proses kegiatan belajar mengajar. Daya tangkap siswa masih cukup rendah dalam menerima pembelajaran, sulit memahami materi, siswa cenderung lupa materi-materi yang pernah diajarakan. Sehingga hasil ujian siswa cenderung menengah kebawah. Berdasarkan hasil temuan di lapangan dan data nilai siswa yang di dapat. Untuk melihat gambaran nilai siswa kelas VII.8 dan VII.9 Berdasarkan hasil temuan di lapangan dan data nilai siswa yang di dapat yaitu data nilai kuis siswa kelas VII. 8 siswa mendapatkan perolehan nilai 50-59 adalah berjumlah 5 peserta didik, perolehan nilai 60-69 berjumlah 12 peserta didik, perolehan nilai 70-79 berjumlah 10 peserta didik, perolehan nilai 80-89 berjumlah 9 peserta didik dan nilai lebih dari 90 sebanyak 3 peserta didik. Selanjutnya siswa kelas VII. 9 yang mendapatkan perolehan nilai 50-59 adalah berjumlah 7 peserta didik, perolehan nilai 60-69 berjumlah 10 peserta didik, perolehan nilai 70-79 berjumlah 10 peserta didik, perolehan nilai $80-89$ berjumlah 9 peserta didik dan perolehan nilai yang lebih dari 90 adalah berjumlah 3 peserta didik. Jumlah peserta didik masing-masing kelas adalah sama yaitu 39 orang peserta didik. 
e-ISSN : 2621-4105

Bertolak belakang dari harapan peningkatan mutu pendidikan yang ingin dicapai, fenomena yang terjadi adalah sistem pembelajaran PPKn masih menampakkan ciri-ciri pembelajaran yang konvensional meskipun di sekolah Madrasah tersebut menggunakan kurikulum 2013. Soemantri mempertegas bahwa kurang bermaknanya PPKn bagi siswa dikarenakan masih dominannya penerapan metode pembelajaran konvensional seperti ground covering technique, indoktrinasi, dan narrative technique dalam pembelajaran PPKn sehari-hari. Anggapan ini diperkuat dengan permintaan siswa agar guru mencatatkan materi pelajaran. ${ }^{8}$

Penelitian ini mengambil suatu model yang yang hampir sama namun variabelnya berbeda untuk meningkatkan pemahaman konsep siswa dan pemahaman kedisiplinan, dengan membandingkan dua model yaitu model Project Citizen dan model Cooperative Script. Penelitian ini melihat nantinya perbandingan dua model ini, manakah yang lebih baik model pembelajaran Project Citizen ataukah Cooperative Script dalam meningkatkan pemahaman konsep siswa dan pemahaman kedisiplinan dalam materi norma hukum.

Pertama model pembelajaran Project Citizen, adalah suatu instructional treatment yang berbasis masalah untuk mengembangkan pengetahuan, kecakapan, dan watak kewarganegaraan demokratis yang memungkinkan dan mendorong keikutsertaan dalam pemerintahan dan masyarakat sipil civil society. ${ }^{9}$ Model pembelajaran yang dapat diterapkan supaya siswa dapat berpartisipasi secara aktif dan kreatif adalah dengan Project Citizen, dengan model ini siswa berusaha membentuk identitas mereka sendiri dan membina hubungan dengan masyarakat, sebagian besar pada masa remaja, siswa mulai bergeser pemikirannya dari berfikir konkret menuju berfikir abstrak, para siswa berusaha menggali nilai-nilai yang menurut mereka baikatau buruk,sah atau tidak sah. ${ }^{10}$

Di dalam pembelajaran di kelas dengan menggunakan Project Citizen siswa diajak untuk memecahkan masalah riil atau nyata dalam kehidupan bermasyarakat, berbangsa dan bernegara. Disini siswa belajar menemukan alternatif pemecahan masalah. Disamping itu, siswa juga mengembangkan proses penalaran dan klarifikasi nilai.

\footnotetext{
${ }^{8}$ N. Soemantri, 2001, “Menggagas Pembaharuan Pendidikan IPS”, Bandung: Remadja Rosdakarya.

${ }^{9}$ Dasim Budimansyah, 2009, "Inovasi Pembelajaran Project Citizen", Bandung: Program Studi Pendidikan Kewarganegaraan SPs Universitas Pendidikan Indonesia.

${ }^{10}$ Dasim Budimansyah, "Revitalization of Citizenship Education Learning through Project Citizen Practice". Jurnal Acta Civicus, 1 (2), 2008, hal 179-198.
} 
e-ISSN : 2621-4105

Kemudian siswa mengembangkan usul kebijakan publik dan mengusulkan rencana tindakan.

Kedua model pembelajaran Cooperative Script adalah pembelajaran yang mengatur interaksi siswa seperti ilustrasi kehidupan sosial siswa dengan lingkungannya sebagai individu, dalam keluarga, kelompok masyarakat, dan masyarakat yang lebih luas. ${ }^{11}$ Ahli lain mengatakan bahwa model belajar Cooperative Script adalah "model belajar dimana siswa bekerja secara berpasangan dan bergantian secara lisan mengikhtisarkan, bagianbagian dari materi yang dipelajari”. Jadi model pembelajaran Cooperative Script merupakan penyampaian materi ajar yang diawali dengan pemberian wacana atau ringkasan materi ajar kepada siswa yang kemudian diberikan kesempatan kepada siswa untuk membacanya sejenak dan memberikanatau memasukkan ide-ide atau gagasangagasan baru kedalam materi ajar yang diberikan guru, lalu siswa diarahkan untuk menunjukkan ide-ide pokok yang kurang lengkap dalam meteri yang ada secara bergantian sesama pasangan masing-masing. ${ }^{12}$ Menurut A'la model pembelajaran Cooperative Script disebut juga skrip kooperatif adalah "metode belajar dimana siswa bekerja berpasangan dengan secara lisan mengiktisarkan bagian-bagian dari materi yang dipelajarinya dalam ruangan kelas." 13

Pemahaman konsep siswa dalam penelitian ini diperoleh dengan cara menganalisis distribusi frekuensi hasil pre test dan post test yang telah dijawab oleh peserta didik pada kedua kelas eksperimen. Distribusi frekuensi nilai hasil pre test peserta didik kelas eksperimen 1 dapat dilihat pada tabel 5 sedangkan distribusi frekuensi hasil post test kelas eksperimen dapat dilihat pada tabel 6.

Tabel 3. Distribusi Frekuensi Pemahaman Konsep Pre Test

\begin{tabular}{cccc}
\hline Rentang Nilai & Frekuensi & Persentase & Kategori \\
\hline$>73.02$ & 3 & $7.69 \%$ & Sangat Tinggi \\
$65.96-73.02$ & 8 & $20.51 \%$ & Tinggi \\
$58.92-65.96$ & 18 & $46.15 \%$ & Sedang \\
$51.86-58.92$ & 7 & $17.94 \%$ & Rendah \\
$\leq 51.86$ & 3 & $7.69 \%$ & Sangat Rendah \\
\hline Jumlah & 39 & $100 \%$ & \\
\hline
\end{tabular}

${ }^{11}$ Sutrisno Hadi, 2007, "Statistik", Yogyakarta : Andi.

${ }^{12}$ Mahisa Alit, 2002, "Pembelajaran Kooperatif, Apa dan Bagaimana". Cirebon: SD Negeri 2 Bungko Lor.

${ }^{13}$ Miftahul A’la, 2011, “Quantum Teaching”, Yogyakarta: Diva Press. 
Berdasarkan tabel di atas terdapat 3 siswa yang mendapat nilai $\leq 51,86$ atau kategori sangat rendah, dan 3 siswa mendapat nilai > 73,02 atau kategori sangat tinggi.

Tabel 4. Distribusi Frekuensi Pemahaman Konsep Post Test

\begin{tabular}{llll}
\hline Rentang Nilai & Frekuensi & Persentase & Kategori \\
\hline$>87.94$ & 3 & $7.69 \%$ & Sangat Tinggi \\
$82.82-87.94$ & 9 & $23.07 \%$ & Tinggi \\
$77.70-82.82$ & 16 & $41.02 \%$ & Sedang \\
$72.58-77.70$ & 10 & $25.64 \%$ & Rendah \\
$\leq 72.58$ & 1 & $2.56 \%$ & Sangat Rendah \\
\hline Jumlah & 39 & $100 \%$ & \\
\hline
\end{tabular}

Berdasarkan tabel di atas terdapat 1 siswa yang mendapat nilai $\leq 72.58$ atau kategori sangat rendah, dan 3 siswa mendapat nilai besar dari 87.94 atau kategori sangat tinggi.

Pemahaman konsep peserta didik kelas eksperimen 2 dapat dilihat dari hasil distribusi nilai pre test dan nilai post test. Distribusi frekuensi Pemahaman Konsep Siswa Kelas Eksperimen 2 dapat dilihat pada tabel 7 untuk nilai pre test dan tabel 8 untuk nilai post test.

Tabel 5 Distribusi Frekuensi Pemahaman Konsep Pre Test

\begin{tabular}{llll}
\hline Rentang Nilai & Frekuensi & Persentase & Kategori \\
\hline$>72.90$ & 3 & $7.69 \%$ & Sangat Tinggi \\
$66.35-72.90$ & 8 & $20.51 \%$ & Tinggi \\
$59.81-66.35$ & 22 & $56.41 \%$ & Sedang \\
$53.26-59.81$ & 5 & $12.82 \%$ & Rendah \\
$\leq 53.26$ & 1 & $2.56 \%$ & Sangat Rendah \\
\hline Jumlah & 39 & $100 \%$ & \\
\hline
\end{tabular}


e-ISSN : 2621-4105

Berdasarkan tabel di atas terdapat 1 siswa yang mendapat nilai $\leq 53.26$ atau kategori sangat rendah, dan 3 siswa mendapat nilai $>72.90$ atau kategori sangat tinggi.

Tabel 6. Distribusi Frekuensi Pemahaman Konsep Post Test

\begin{tabular}{llll}
\hline Rentang Nilai & Frekuensi & Persentase & Kategori \\
\hline$>82.11$ & 1 & $2.56 \%$ & Sangat Tinggi \\
$77.45-82.11$ & 13 & $33.33 \%$ & Tinggi \\
$71.81-77.45$ & 12 & $30.76 \%$ & Sedang \\
$68.15-72.81$ & 12 & $30.76 \%$ & Rendah \\
$\leq 68.15$ & 1 & $2.56 \%$ & Sangat Rendah \\
\hline Jumlah & 39 & $100 \%$ & \\
\hline
\end{tabular}

Berdasarkan tabel di atas terdapat 1 siswa yang mendapat nilai $\leq 68.15$ atau kategori sangat rendah, dan 1 siswa mendapat nilai > 82.11 atau kategori sangat tinggi.

Tabel 7. Nilai Rata-Rata Kelas Eksperimen 1 dan Eksperimen 2

\begin{tabular}{lll}
\hline Variabel & Kelas eksperimen 1 & Kelas eksperimen 2 \\
\hline Pre test & 62,44 & 63,08 \\
Post test & 80,26 & 75,13 \\
Selisih & 17,82 & 12,05 \\
\hline
\end{tabular}

Berdasarkan tabel di atas Nilai rata-rata post test kelas eksperimen 1 (80.26) lebih tinggi dibanding nilai rata-rata post test kelas eksperimen 2 (75.13).

\section{Hasil Pemahaman Kedisiplinan Siswa melalui Konsep Norma Hukum}

Kedisiplinan Siswa peniliti lihat dari sebaran distribusi frekuensi skor hasil pengisian angket yang telah peneliti sebar pada kedua kelas eksperimen. Hasil distribusi frekuensi kedisiplinan siswa dapat dilihat pada tabel 10. 
e-ISSN : 2621-4105

Tabel 8. Distribusi Frekuensi Kedisiplinan Siswa

\begin{tabular}{|l|l|l|l|}
\hline \multirow{2}{*}{ Nilai Kedisiplinan } & \multicolumn{2}{|c|}{ Distribusi Frekuensi } & \multirow{2}{*}{ Kategori } \\
\cline { 2 - 3 } & Eksperimen 1 & Eksperimen 2 & \\
\hline$<35$ & 0 & 0 & Rendah \\
\hline $35-65$ & 9 & 12 & Cukup \\
\hline$>65$ & 30 & 27 & Tinggi \\
\hline Jumlah & 39 & 39 & \\
\hline
\end{tabular}

Berdasarkan tabel di atas dapat dilihat siswa yang memiliki tingkat kedisiplinan tinggi pada kelas eksperimen 1 (30 orang), lebih banyak dibanding siswa yang memiliki tingkat kedisiplinan tinggi pada kelas eksperimen 2 (27 orang). Selanjutnya perbandingan kelas eksperimen 1 dengan kelas eksperimen 2 dapat dihitung dengan uji-t seperti yang ditampilkan pada tabel 11 untuk tingkat pemahaman konsep siswa dan tabel 12 untuk kedisplinan siswa.

\section{Tabel 9. Hasil Perhitungan Uji Hipotesis (Uji-t) Pemahaman Konsep Siswa}

\begin{tabular}{lll}
\hline Variabel & Eksperimen 1 & Eksperimen 2 \\
Jumlah siswa $(\mathrm{n})$ & 39 & 39 \\
Nilai rata-rata $(\Delta)$ & 80,26 & 75,13 \\
Standar Deviasi $(\mathrm{S})$ & 5,123 & 4,658 \\
Thitung & & 4,625 \\
Ttabel & & 1,665 \\
Pvalue & & 0.000 \\
\hline
\end{tabular}

Berdasarkan tabel di atas diketahui uji hipotesis pada kelas eksperimen 1 dan kelas eksperimen 2 telah memenuhi kriteria pengujian yaitu thitung>ttabel. Dimana hasil perhitungan uji hipotesis pada kedua kelas eksperimen didapatkan hasil bahwa thitung sebesar 4,625 dan ttabel Sebesar 1,665. Pvalue < 0.05 (0.000). Hasil ini sesuai dengan kriteria pengujian, artinya hipotesis nol (Ho) ditolak dan hipotesis alternatif (Ha) yang 
e-ISSN : 2621-4105

diterima. Data hipotesis ini menunjukkan bahwa terdapat perbedaan yang signifikan antara pemahaman konsep siswa pada pembelajaran PPKn pada kelas eksperimen I yang menerapkan model pembelajaran Project Citizen dan kelas eksperimen II yang menerapkan model pembelajaran Cooperative Script.

Tabel 10. Hasil Perhitungan Uji Hipotesis (Uji-t) Kedisiplinan Siswa

\begin{tabular}{lll}
\hline Variabel & Eks 1 & Eks 1 \\
\hline Jumlah siswa $(\mathrm{n})$ & 39 & 39 \\
Nilai rata-rata $(\Delta)$ & 66,41 & 66,05 \\
Standar Deviasi $(\mathrm{S})$ & 3,015 & 2,828 \\
Thitung & & 0.542 \\
Ttabel & & 1,665 \\
Pvalue & & 0.589 \\
\hline
\end{tabular}

Berdasarkan tabel di atas diketahui uji hipotesis pada kelas eksperimen 1 dan kelas eksperimen 2 telah memenuhi kriteria pengujian yaitu thitung < ttabel. Dimana hasil perhitungan uji hipotesis pada kedua kelas eksperimen didapatkan hasil bahwa thitung sebesar 0.542 dan ttabel sebesar 1,665. Hasil ini sesuai dengan kriteria pengujian, artinya hipotesis nol (Ho) diterima dan hipotesis alternatif (Ha) yang ditolak. Data hipotesis ini menunjukkan bahwa tidak terdapat perbedaan yang signifikan antara kedisiplinan siswa pada kelas eksperimen 1 yang menerapkan model pembelajaran Project Citizen dan kelas eksperimen 2 yang menerapkan model pembelajaran Cooperative Script.

Ada tidaknya perbedaan yang signifikan antara pemahaman konsep pada pembelajaran PPKn khususnya pada pokok bahasan norma hukum pada kelas yang menerapkan model pembelajaran Project Citizen dan kelas yang menerapkan model Cooperative Script dapat dilihat dari hasil belajar siswa. Hasil belajar siswa tersebut dapat dilihat dari perbandingan Pre test kedua kelas seperti ditunjukkan pada gambar 1a, perbandingan nilai post test dari kedua kelas seperti yang ditunjukkan pada gambar $1 \mathrm{~b}$ dan perbandingan selisih nilai Pre test dan post test siswa dari kedua kelas eksperimen seperti terlihat pada gambar 2 . 


\section{Gambar 1 Perbandingan nilai Pre test dan nilai post test kedua kelas}

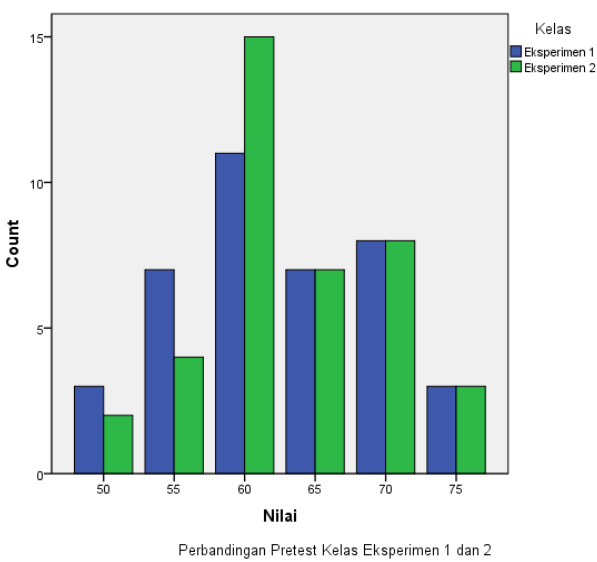

a. Perbandingan nilai pre test

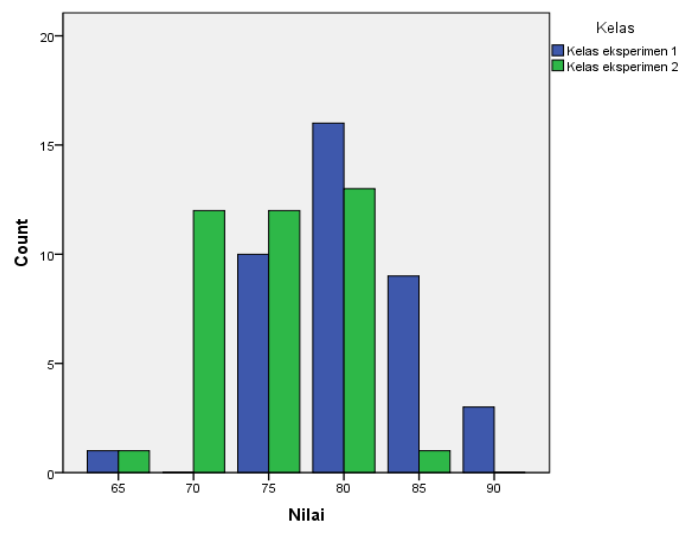

Perbandingan Post Test Kelas Eksperimen 1 dan 2

b. Perbandingan nilai post test

Dari Gambar 1a terlihat bahwa nilai rata-rata pre test siswa untuk kedua kelas eksperimen masih rendah. Karena jika dilihat dari Kriteria Ketuntasan Minimal (KKM) yaitu 75, sangat jelas bahwa semua nilai pre test siswa dari kedua kelas eksperimen belum mencapai ketuntasan. Hal ini menunjukkan bahwa pengetahuan siswa, baik pada kelas eksperimen I dan kelas eksperimen II tentang materi yang akan dipelajari masih kurang. Kekurangan ini dikarenakan siswa tidak memiliki persiapan yang matang terlebih dahulu sebelum pembelajaran dimulai mengenai materi norma hukum, sehingga tidak mampu menyelesaikan soal pre test dengan baik. Di akhir pembelajaran, dilakukan post test pada kedua kelas eksperimen tersebut untuk melihat seberapa besar peningkatan pengetahuan yang diperoleh siswa selama proses belajar mengajar yang telah dilakukan. Dari hasil penelitian yang diperoleh, pada pertemuan pertama dan kedua didapatkan nilai rata-rata post test. Dimana nilai rata-rata post test untuk kelas eksperimen I yang menerapkan model pembelajaran Project Citizen dan kelas eksperimen II yang menerapkan model pembelajaran Cooperative Script berturut-turut adalah 80,26 dan 75,13. Perbandingan nilai post test kedua kelas eksperimen dapat dilihat pada gambar $1 \mathrm{~b}$. Dari gambar $1 \mathrm{~b}$ terlihat bahwa siswa dari kedua kelas eksperimen telah mengalami peningkatan pengetahuan setelah diterapkan model pembelajaran. Pada kelas eksperimen I jumlah siswa yang mendapatkan nilai post test di atas KKM 75 sebanyak 30 orang siswa, sedangkan untuk kelas eksperimen II jumlah siswa yang mendapatkan nilai post test di 
e-ISSN : 2621-4105

atas KKM 75 sebanyak 19 orang siswa. Hal ini menunjukkan bahwa pembelajaran yang dilakukan pada kedua kelas eksperimen sudah dapat diterima oleh siswa. Dari hasil nilai post test siswa, terlihat bahwa jumlah siswa yang mendapatkan nilai post test di atas KKM 75 lebih banyak kelas eksperimen II dibandingkan dengan kelas eksperimen I. Hal ini menunjukkan bahwa proses pembelajaran materi norma hukum dengan menerapkan model Project Citizen dapat menghasilkan peningkatan pengetahuan ranah kognitif lebih baik dibandingkan pembelajaran dengan menerapkan model Cooperative Script.Seberapa besar peningkatan hasil belajar kognitif siswa dapat dilihat dari selisih nilai pre test dan post test yang diperoleh siswa. Peningkatan hasil belajar siswa pada ranah kognitif untuk kedua kelas eksperimen dapat dilihat pada gambar dibawah 2.

\section{Gambar 2 Perbandingan hasil eksperimen 1 dan eksperimen 2}

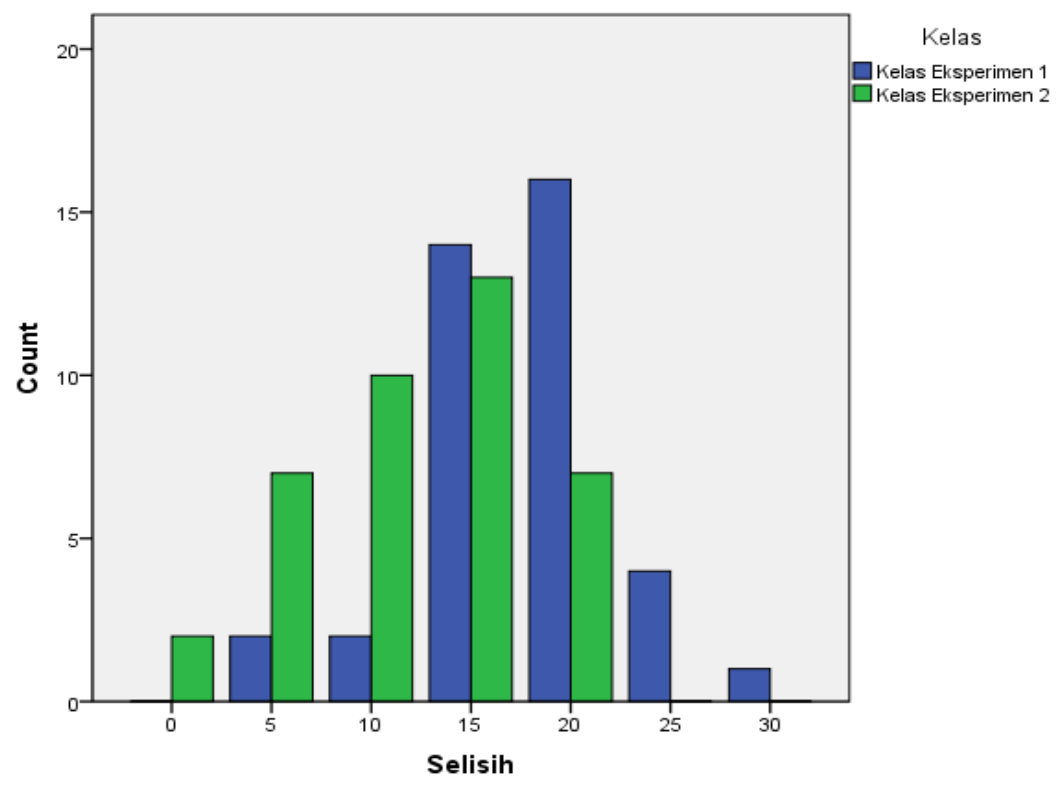

Perbandingan Peningkatan Hasil Belajar Kelas Eksperimen 1 dan 2

Dari Gambar 2 terlihat bahwa peningkatan hasil belajar ranah kognitif siswa memang lebih baik pada kelas eksperimen I dibandingkan dengan kelas eksprimen II. Dimana peningkatan hasil belajar siswa pada kelas eksperimen I lebih banyak berada pada rentang nilai 60-70 sedangkan untuk kelas eskperimen II peningkatan hasil belajarnya lebih banyak pada rentang nilai 55-60. Hal ini juga dapat diketahui dengan melihat rata-rata peningkatan hasil belajar kognitif kedua kelas eksperimen. Nilai ratarata peningkatan hasil belajar kognitif kelas eksperimen I dan kelas eksperimen II 
e-ISSN : 2621-4105

berturut-turut adalah 17,82 dan 12,05. Makin besar rentang selisih nilai yang diperoleh, makin besar pula peningkatan hasil belajar yang didapatkan. Sehingga, dapat dinyatakan bahwa hasil belajar siswa ranah kognitif pada kelas eksperimen I yang menerapkan model pembelajaran Project Citizen lebih baik dibandingkan kelas eksperimen II yang menerapkan model Cooperative Script. Hal tersebut disebabkan karena pada kelas eksperimen I siswa diberikan kesempatan untuk memecahkan masalah atau LDS secara mandiri terlebih dahulu tujuannya supaya siswa tersebut dapat mencurahkan ide mereka sendiri dalam menyelesaikan masalah tersebut sebelum akhirnya bersama mendiskusikan hasil kerja yang diperoleh dan dipresentasikan kedepan kelas. Ini artinya semua siswa diberi tanggung jawab yang sama dalam menyelesaikan permasalahan dan diberi kesempatan untuk bepikir mandiri dahulu sebelum bertukar pendapat. Hal ini membuat siswa memiliki waktu yang lebih banyak untuk berpikir dan membuat semua siswa lebih aktif karena keingintahuan mereka semakin besar. Untuk menguji hipotesis apakah terdapat perbedaan yang signifikan antara hasil belajar ranah kognitif penerapan model pembelajaran Project Citizent dan model pembelajaran Cooperative Script pada pokok bahasan norma hukum, dilakukan uji t dengan menggunakan data peningkatan hasil belajar kognitif yang diperoleh. Dari uji t yang dilakukan berdasarkan data dari nilai ratarata peningkatan hasil belajar ranah kognitif diperoleh t hitung adalah 3,16. Sedangkan ttabeladalah 2,66. Hal ini artinya hipotesis alternatif (Ha) diterima. Jadi, ada perbedaan yang signifikan antara hasil belajar ranah kognitif siswa pada model pembelajaran Project Citizen dan model pembelajaran Cooperative Script pada pokok bahasan norma hukum.

Selanjutnya adalah angket yang disebar kepada siswa sebelum dan setelah diberikan perlakuan yaitu melihat pemahaman siswa mengenai norma hukum dengan mengisi angket yang di dalam angket tersebut dalam bentuk sikap nanti siswa memilih selalu, sering, kadang-kadang, jarang dan tidak pernah dari hasil skala likert yang di dapat menyatakan bahwa hasil eksperimen 1 lebih baik dari hasil eksperimen 2 . Untuk Kedisiplinan siswa antara model pembelajaran dengan Project Citizen dan cooperative script tidak ada perubahan yang signifikan. Hal itu disebabkan oleh keterbatasan penelitian. 
e-ISSN : 2621-4105

\section{E. PENUTUP}

Dari hasil penelitian dapat disimpulkan bahwa nilai rata-rata pemahaman konsep siswa pada kelas eksperimen 1 Project Citizen lebih tinggi dari pada kelas eksperimen 2 Cooperative Script.Terdapat perbedaan yang signifikan pemahaman konsep siswa yang dilakukan pada kelas eksperimen 1 Project Citizen dengan kelas eksperimen 2 Cooperative Script. Dari penelitian didapatkan hasil tingkat kedisiplinan siswa kategori tinggi lebih banyak pada siswa kelas eksperimen 1 Project Citizen dibanding dengan kelas eksperimen 2 Cooperative Script. Berdasarkan hal ini dapat disimpulkan bhawa tidak terdapat perbedaan signifikan kedisiplinan siswa pada kelas eksperimen 1 Project Citizen dengan kelas eksperimen 2 Cooperative Script. Untuk meningkatkan pemahaman konsep siswa pada kegiatan pembelajaran dengan menerapkan model pembelajaran Project Citizen sebaiknya semua siswa dalam satu kelompok memiliki sumber belajar yang lebih banyak selain dari buku cetak yang mereka miliki sedangkan pada kegiatan model pembelajaran Cooperative Script ketika menyelesaikan masalah sebaiknya siswa dipasangkan dengan teman yang tingkat kemampuannya berbeda atau heterogen agar pendapat siswa bervariasi. Disamping itu agar siswa lebih bersemangat saat pembelajaran maka hendaknya guru lebih meningkatkan motivasi siswa misalnya dengan cara memberikan reward berupa nilai tambahan untuk siswa yang telah berani mengemukakan pendapatnya atau dengan memberikan pujian.

\section{DAFTAR PUSTAKA}

\section{Buku}

Achmad Patoni. 2004, "Dinamika Pendidikan Anak”. Jakarta: PT. Bina Ilmu.

Miftahul A'la, 2011, "Quantum Teaching”, Yogyakarta: Diva Press.

Mahisa Alit, 2002, "Pembelajaran Kooperatif, Apa dan Bagaimana". Cirebon: SD Negeri 2 Bungko Lor

Dasim Budimansyah, 2009, “Inovasi Pembelajaran Project Citizen”, Bandung: Program Studi Pendidikan Kewarganegaraan SPs Universitas Pendidikan Indonesia.

Sutrisno Hadi, 2007, "Statistik”, Yogyakarta : Andi.

Kokom Komalasari, 2011, "Pembelajaran Kontekstual Konsep dan Aplikasi”, Bandung : Refika Aditama.

Moch. User Usman, 2011, “Menjadi Guru Profesional”, Bandung : Remaja Rosdakarya. 
e-ISSN : 2621-4105

Sapriya, dan US Winataputra, 2004, "Pendidikan Kewarganegaraan:Model Pengembangan Materi Dan Pembelajaran” Bandung:Lab. PKn UPI Bandung.

N. Soemantri, 2001, "Menggagas Pembaharuan Pendidikan IPS", Bandung: Remadja Rosdakarya.

Yuliandri, "Asas-Asas Pembentukan Peraturan Perundang-Undangan Yang Baik', Jakarta:PT Raja Grafindo Persada, 2009.

\section{Jurnal}

Aisah Novita Nurhidayati, Edy Purnomo, Nurdin, "Hasil Belajar Antara Kooperatif SFAE dan Cooperative Script dengan Memperhatikan Sikap, Jurnal Edukasi Ekobis 3 (2), 2015.

Dasim Budimansyah, "Revitalization of Citizenship Education Learning through Project Citizen Practice". Jurnal Acta Civicus, 1 (2), 2008.

Hafidh, Maksum, "Model Project Citizen Dalam Mengembangkan Sikap Nasionalisme Bagi Mahasiswa PGMI UIN Ar-Raniry Banda Aceh", Jurnal Pionir 4 (2), 2015.

DOI: http://dx.doi.org/10.22373/pjp.v4i2.179

Nika Fetria Trisnawati dkk, "Pengaruh Model Cooperative Script Terhadap Hasil Belajar Siswa Kelas IX SMP Negeri 1 Kota Sorong”, Jurnal ADMATHEDU 9 (2), 2019.

DOI: http://dx.doi.org/10.12928/admathedu.v9i2.14858

Ni Pt. Dyan Febriyanti1, I Nym. Laba Jayanta, "Pengaruh Model Pembelajaran Cooperative Script Berbantuan Penilaian Portofolio terhadap Hasil Belajar PKn", $\begin{array}{llllll}\text { Jurnal Mimbar PGSD UNDHIKSA } 6 & \text { (2) } 2018 .\end{array}$ DOI: http://dx.doi.org/10.23887/jjpgsd.v6i2.19468

Norlaili Hidayati, "Meningkatkan Kecakapan Kewarganegaraan (Civic Skill) Melalui Pembelajaran Pkn Berbasis Project Citizen (Studi Kuasi Eksperimen Di SMK YPT Banjarmasin)”, Jurnal Socius 2 (2), 2013.DOI: 10.20527/jurnalsocius.v2i2.2205

Rima Vien Permata Anita Trisiana. Implementasi Model Pembelajaran Pilot Project Citizen Berbasis Nasionalisme pada Pendidikan Kewarganegaraan Demi Mewujudkan Karakter Peserta Didik. Jurnal Ketahanan Nasional 17 (3), 2012. https://doi.org/10.22146/jkn.22697

Sara Winstead FRY dan Adil Bentahar, "Student Attitudes Towards and Impressions of Project Citizen”, Journal of Social Studies Education Research 4 (1) 2013.

\section{Internet}

Mariani,Scolastika.2009. Peningkatan kualitas pembelajaran. (http://scmarianiunnes.blogspot.com/). 